\title{
Participation Dynamics of Voters Using ID Card in Local Elections: A Case Study of the 2015 Local Election in South Sulawesi
}

\author{
Andi Ahmad Yani ${ }^{1}$ \\ Andi Yudha Yunus ${ }^{2}$ \\ Muhammad Iqbal Latief ${ }^{3}$
}

\begin{abstract}
The number of voters is an essential element in the legitimacy of a democratic regime. There are various factors that may influence voter turnout in elections; among other factors particularly is electoral management in voter's registration. The problem of voters' data has always been a scourge in every general or local election due to poor population data management in Indonesia. Hence, the General Elections Commission (KPU) responded to this issue with a number of policies to increase the number of voter participation in all elections, especially for those who have not been registered properly. The Commission made a specific regulation to allow voters who were not registered in the voter lists (DPS) to use their ID card (KTP) or other legal documents in voting. This study used qualitative methods in five regions in the South Sulawesi Province that conducted the 2015 local election. This study explores the dynamics of voters using ID card or other legal documents by identifying their reasons and characteristics in using KTP as well as examining the responses of the local election institutions regarding this policy. This condition tends to apply to countries in the transitional period of democracy where the electoral administration system has not been properly regulated. The causes include the failure of administrative systems of management and population data collection with e-KTP system in Indonesia.
\end{abstract}

\section{Keywords:}

voter participation; local election; local politics; voter registration.

\begin{abstract}
Abstrak
Jumlah pemilih merupakan elemen penting dalam legitimasi rezim demokratis. Ada berbagai faktor yang mempengaruhi pemilih dalam pemilihan; Di antara faktor-faktor lainnya terutama adalah manajemen pemilihan dalam pendaftaran pemilih. Masalah data pemilih selalu menjadi momok dalam setiap pemilihan umum atau lokal karena pengelolaan data penduduk yang buruk di Indonesia. Oleh karena itu, Komisi Pemilihan Umum (KPU) menanggapi masalah ini dengan sejumlah kebijakan untuk meningkatkan

\footnotetext{
1 Faculty of Social and Political Sciences, Hasanuddin University

Email: aayani@unhas.ac.id

2 Faculty of Social and Political Sciences and Director of the Political Party Center, Pejuang Republik Indonesia University, Makassar

Email: y_yunus2002@yahoo.com

3 Faculty of Social and Political Sciences, Hasanuddin University

Email: muhilberkelana@gmail.com
} 
jumlah partisipasi pemilih dalam semua pemilihan, terutama bagi yang belum terdaftar dengan benar. Komisi membuat peraturan khusus untuk mengizinkan pemilih yang tidak terdaftar dalam daftar pemilih (DPS) untuk menggunakan KTP atau dokumen hukum lainnya dalam pemungutan suara. Penelitian ini menggunakan metode kualitatif di lima wilayah di Provinsi Sulawesi Selatan yang menyelenggarakan Pemilu 2015. Studi ini membahas dinamika pemilih dengan menggunakan KTP atau dokumen hukum lainnya dengan mengidentifikasi alasan dan karakteristik mereka dalam menggunakan KTP serta memeriksa tanggapan lembaga pemilihan lokal mengenai kebijakan ini. Kondisi ini cenderung berlaku bagi negaranegara dalam masa transisi demokrasi dimana sistem administrasi pemilu belum diatur dengan baik. Penyebabnya antara lain adalah kegagalan sistem administrasi pengelolaan dan pendataan penduduk dengan sistem e-KTP di Indonesia.

\section{Kata kunci:}

partisipasi pemilih; pemilihan lokal; politik lokal; pendaftaran pemilih.

\section{Introduction}

Voter participation in general elections has always been one of the main indicators in the implementation of representative democracy. The citizens' attendance in elections to exercise their voting rights is a form of legitimacy a political system has over the citizenry. In other words, the more citizens use their right to vote in an election, the stronger the democratic system of that country presumably is. This is founded on the basic frame of thought that the people's support in general elections becomes the basic foundation of a democratic political system.

Nevertheless, in reality, the rate of voter participation in elections tends to fluctuate. Developed democratic countries are instead observed to have low rates of election participation. Based on data from the Institute for Democracy and Electoral Assistance (IDEA) (2016) the rate of citizen participation in Germany during the 2013 parliamentary election was at $71.5 \%$. The United States had a lower participation rate which was $68.3 \%$ in the 2016 legislative election. This percentage is almost similar to its neighbor, Canada, which had a voter participation rate of $68.3 \%$ in the 2015 general election. England had an even lower voter participation rate for the 2015 general election at $66.1 \%$. Lastly, the French citizen participation in the 2012 parliamentary election was far lower at only 55.4\% (IDEA, 2016).

Meanwhile, countries undergoing democratic transition process demonstrate quite a high rate of participation. IDEA (2016) data shows that the participation of Filipinos in the 2016 general election was as much as $82 \%$. The participation of Malaysians in the 2013 general election was at $84 \%$. Brazilians also had a high participation rate in the 2014 general election with an $80.6 \%$ turnout. South African citizens were very active in exercising their political rights in the elections with a rate of $73.5 \%$ turnout in the last legislative election of 2014. As for Indonesia, it had witnessed a participation rate of $75.1 \%$ in the 2014 legislative election, which is an increase compared to the 2009 general election which was at 71\%.

Based on the comparison of the two groups above, it is observed that voter's participation rates in general elections differ in every country, regardless of the level of stability of a particular political system's democratic quality. Regarding the matter, various studies have elaborated on several factors affecting the trend in the fluctuation of voter participation rate (Stockemer et al., 2013; Solt, 2010; Geys, 2006; Blais et al., 2003; Oliver, 2000; Powel, 1982; Lipset, 1981; Verba and Nie, 1972). Based on these study analyses, this research has identified three main determinants 
affecting the number of citizen participation in exercising their right to vote, namely: (1) social economic factor; (2) political trust factor; and (3) institutional factor.

Firstly, the social economic factor is the main determinant affecting voter participation rate (Solt, 2010; Geys, 2006; Blais et al., 2003; Oliver, 2000; Powel, 1982; Lipset, 1981; Verba and Nie, 1972). Furthermore, Powel (ibid) explained that the quality of social and economic development of a country impacts the community's level of access to information and education. These two factors trigger the people's political awareness, and difference of interests among the groups further motivates them to be involved in the political process by exercising their right to vote.

Related studies were conducted by Verba and Nie (1972) and Oliver (2000) which analyzed the population factor, indicating that a country with smaller area tend to have higher voter participation as communication can be more effectively conducted. In another study, Lipset (1981) elaborated further by analyzing population density in which he argues that the more concentrated the population, the easier it is to mobilize. Thus is also the case with a study conducted by Blais et al. (2003) which explored the voter participation phenomenon in a comparative study of voter's turnout in a number of countries in Europe, Africa, and America. The study results indicate that the number of voter turnout is higher in countries with lower economic level and population compared to countries in North America and Eastern Europe. Furthermore, Blais et al. (ibid) also identified that voter rate variations in some countries may possibly be influenced by the political culture of a particular area.

Solt (2010) more specifically found a tendency of low voter participation in a country because it is influenced by the breadth of prevailing economic gap. Another study undertaken by Geys (2006) also asserted that social economic factor is one of the substantial factors affecting voter participation rate. Geys (ibid) analyzed the social economic factor based on the population, concentration of population in a given area, and population diversity based on income and ethnicity. This study re-emphasizes previous studies that social economic factors contribute in changing the rate of voter participation in a country.

Secondly is factor which influences participation in general elections is the quality of the people's political trust. The value of trust is a major foundation in ensuring the continuity of legitimacy a democratic system wields (Yani, 2015). Political trust is the hope and result of citizen evaluation over the performances of political institutions and leaders in implementing democratic values (Yani, 2015; Grimmelikhuijsen, 2012; Wong et al., 2011; Bourne, 2010). Regarding the voter participation rate, a study conducted by Grönlund and Setälä (2007) shows that political trust significantly affects voter turnout on election day. At the individual level, a person's level of political trust influences their awareness to actively voice their political rights in the general election (ibid).

In another study, Stockemer et al. (2013) found that corruption cases have a tremendous influence on the voter participation rate a country has. Stockemer et al. (ibid) analyzed that rampant corruption has an impact on the people's low level of satisfaction toward democratic institutions which ultimately influences the quality of political trust the people have toward the government. This is strengthened by a study conducted by Wagner et al. (2009) which asserts that residents do not want to interact with leaders elected through general elections as they are considered to be part of the corrupt political system. In other words, the low level of political trust people garner toward a government regime can undermine their intention of exercising their right to vote in the election (ibid).

Lastly is the factor pertains to institution, be it the election administering institution 
(General Elections Commission - KPU) or other matters that fall in the purview of government institutions (central, provincial, and regional/ municipal governments) in supporting the election process, such as policies on budget restriction, budget amendment, availability of initiative based policies, number of legislators, tax policy, and single party domination in the parliament and government (Aminuddin, 2016; Rolfe, 2012; Geys, 2006; Merrifield, 1993). A study conducted by Merrifield (1993) states that voter turnout is not merely caused by macro factors as elaborated by various prior political studies, the institutional factor is in fact more influential in the fluctuation of voter participation rate. Aminuddin (2016) identified that election system engineering may enable political party to be closer with its constituencies. This condition enables political party organizers and legislative candidates to persuade their constituencies in becoming more active in exercising the voting rights. Rolfe (2012) more specifically analyzed institutional factor which influences voter participation including election administering institution, voter registration process, and election expenditure. This is in line to the study conducted by Geys (2006) which also included the institution variable as one of the determinants bearing influence on the trend of citizens exercising their voting rights. Geys (ibid) analyzed the indicators of the institution variable which were the election system, policies related to rights or obligations in exercising voting rights, concurrent election conduction, and voter registration process.

Regarding the election conditions in Indonesia, the institutional factor is one of the substantial determinants of voter participation in general elections or local elections, particularly concerning the management of voter registration. The unfavorable conditions of civil registry in Indonesia affects the validity of voter's data in the conduction of general or local elections. This condition is further exacerbated with the lack of management in updating voter's data prior to the conduction of general or local elections. The updating process was instead not being used to improve the quality of voter's registry, as the fact remains that there were still residents not properly registered which led to their political rights becoming obscured as they were not registered in the Permanent Voters List (DPT). In response to this phenomenon, the General Elections Commission (KPU) subsequently issued a policy for unregistered voters in the DPT to use their Identity Card (KTP) or other identifications such as Family Registry and Passport to vote. This policy is widely known as PKPU No. 10 Year 2015 on Polling and Counting of Votes for the Election of Governor and Vice Governor, Regent and Vice Regent, and or Mayor and Vice Mayor. This policy is expected to increase the rate of voter's participation so that no Indonesian citizen loses their right to vote.

Based on these conditions, it is important to know the impact of the policy on using KTP or other identity documents on the voters and also on future election management. Although this policy bears positive goals, it also has the potential of obtaining negative results by allowing the opportunity for deceit and fraud. This article is composed based on a study analyzing the dynamics of voters using KTP and other identity documents as a result of the above policy. This study further explored the characteristics and responses of voters using KTP and other identity documents. Additionally, this study also more deeply analyzed the responses of Regional/Municipal KPU, Elections Supervisory Committee (Panwaslu) and Voter Data Update Officer (PPDP) as they were responsible for execution, monitoring, and updating of voter's data at the local level regarding the possibility of using KTP and other identifications for voters unregistered in the DPT during the 2015 Regional Election in 11 Regencies/Municipalities in South Sulawesi. 


\section{Methods}

This study was conducted using qualitative methodology as it is considered the most effective method for in-depth exploration of data with specific informant characteristics i.e. users of KTP or other identifications in the 2015 local election. This study was conducted between the months of July to August 2016 and it consisted of 5 stages, namely: preparation stage; field research stage; data input stage; data analysis stage; and report composition stage.

This research was carried out in 4 regions representing 11 regions in South Sulawesi which had conducted local elections in 2015. The four regions are Gowa Regency, Pangkep Regency, North Toraja Regency, and North Luwu Regency.

There are two basic rationales in determining the four regions as the focus of this research. Firstly, the four regions had users of KTP or other identifications in the 2015 local election, as shown in Table 1 below. Secondly, the four regions signified the local geo-political characteristics representative of the 4 major ethnicity existing in South Sulawesi, wherein the Gowa Regency represented the Makassar ethnicity, Pangkep Regency represented the Bugis ethnicity, North Luwu Regency represented the Luwu ethnicity, and North Toraja Regency represented the Toraja ethnicity.

This study employed 3 methods of data collection. First, through in-depth interviews which is a significant research instrument in qualitative study with focus on key informants who are considered well-informed and knowledgeable regarding the research subject matter. By using this method, a more complex and in-depth data can be obtained in relation to the use of KTP or other identifications in the 2015 local election. Second, Focus Group Discussion (FGD) was carried out to confirm a number of information that had been gathered. Additionally, FGD was also carried out to explore several information which focused on an issue involving several people, specifically on the issue of using KTP and other identifications in the 2015 local election. Third, document analysis/study was conducted to dig deeper into policies and programs which had been implemented by the Regional/Municipal KPU and Panwaslu in the four research locations concerning voter participation, particularly regarding users of KTP or other identifications in the 2015 local election.

The main key informants in this research were all users of KTP or other identifications in the 2015 election in the four research locations.

Table 1.

Voters Using KTP and Other identifications 2015 Local Election in South Sulawesi

\begin{tabular}{|c|c|c|c|c|c|}
\hline \multirow{2}{*}{ No. } & \multirow{2}{*}{ Regency } & \multicolumn{3}{|c|}{ KTP Users } & \multirow{2}{*}{ Percentage } \\
\hline & & Male (M) & Female (F) & $\mathbf{M}+\mathbf{F}$ & \\
\hline 1 & Soppeng & 645 & 640 & 1.285 & $0,91 \%$ \\
\hline 2 & Barru & 784 & 819 & 1.603 & $1,58 \%$ \\
\hline 3 & Bulukumba & 2.320 & 2.797 & 5.117 & $2,36 \%$ \\
\hline 4 & Maros & 1.380 & 1.698 & 3.078 & $1,93 \%$ \\
\hline 5 & Pangkep & 1.057 & 1.255 & 2.282 & $1,26 \%$ \\
\hline 6 & Gowa & 3.377 & 4.296 & 7.673 & $2,37 \%$ \\
\hline 7 & Tana Toraja & 1.437 & 1.330 & 2.767 & $2,25 \%$ \\
\hline 8 & North Luwu & 1.550 & 1.607 & 3.157 & $1,85 \%$ \\
\hline 9 & East Luwu & 1.048 & 934 & 1.982 & $1,44 \%$ \\
\hline 10 & Selayar & 393 & 433 & 826 & $1,10 \%$ \\
\hline 11 & North Toraja & 2.775 & 2.889 & 5.664 & $4,30 \%$ \\
\hline & Total & 16.766 & 18.668 & 35.434 & $2,01 \%$ \\
\hline
\end{tabular}

Source: South Sulawesi KPU, 2015 
This study selected a minimum of five key informants in every research location by using a purposive sampling method. The selection of key informants was based on four major indicators. The indicators used to select key informant users of KTP or other identifications in the 2015 local election are as follows:

\section{- Sex}

The majority of key informants interviewed were women with the consideration that women have a high vulnerability level of being coerced to make political choices, particularly in local elections.

\section{- Age}

Key informants were expected to represent the diverse range of electorates by dividing them into two major groups, namely young voters (aged 17-35) and mature voters (aged 36 and above).

\section{- Region}

Key informants were also expected to represent variations of voting locations with focus on two variables which are urban and rural areas. Urban areas were represented by districts found in the regional capital while rural areas were districts located outside the regional capital in the four research locations. The difference in location affects the possibility of mobilizing or intimidating users of KTP or other identifications in the 2015 local election.

Based on the three indicators above, informants were selected using available data on users of KTP from the Regional/ Municipal KPU. In addition to key informants who used KTP or other identifications in the 2015 local election, this study also gathered data and information from local elections administering officers who represented the Regional/Municipal KPU of the respective regions, former members of Panwaslu for the 2015 local election, and voter data update officers (PPDP) who were assigned to register would-be-voters. The study results were subsequently analyzed with a descriptive method by observing the connections of data and information acquired through in-depth interviews and FGD. Additionally, data from document analysis was also used as supporting data to corroborate the established assumption based on analysis of data from FGD and interview results.

\section{Disscusion}

\section{Characteristics of Voters Who Used KTP and Responses of Local Election Administering Institutions}

This study explores the dynamics of voters using KTP and other identifications in the 2015 South Sulawesi Local Election with a focus on two main interrelating components. First: the component of voters using KTP and other identifications in the four research locations conducting the 2015 local election in South Sulawesi. Second: the component of local elections administrators consisting of General Elections Commission (KPU), Elections Supervisory Committee (Panwaslu) in the 2015 local election. Aside from the administrators, this component also relates to voter data update officers (PPDP) who were responsible for voter registration which would then become a reference in determining the Permanent Voters List (DPT) by the Regional/Municipal KPU.

\section{Informant Characteristics}

As elaborated in the research method section, the key informants in this study were people who exercised their right to vote in the 2015 local election by using their KTP or other identifications. This study interviewed 15 women and 15 men in four study areas. Regarding the age of key informants, there were more mature voters ( $>36$ years old) than young voters (17-35 years old). Mature voters using KTP were expected to provide information regarding their experiences in the 
elections they've participated in, relating to the use of KTP and other identifications.

Next, is the education background of informants the majority of them acquired a minimum of high school level education, which is followed by informants with higher education (diploma, bachelor, master) level background. In several studies it is observed that education level affects voter's behavior which would also influence their behavior in using KTP and other identifications.

Geographical factor also influences voter's behavior wherein voters who reside in urban and rural areas may have differing option preference. Additionally, this choice preference may affect voter's reasoning in using KTP and other identifications. This study interviewed more who informants lived in rural areas than in urban areas. In a number of previous election cases, voters in rural areas tended to be more easily mobilized by certain groups to vote for the candidate they support.

\section{Voters Using KTP or Other Identifications in the 2015 Local Election}

This section is focused on understanding the reason why voters used KTP or other identifications. The team of researchers had interviewed 31 key informants who were all selected because they had voted using KTP or other identifications in the 2015 local election at the four research locations. Details on the number of voters according to the research areas are as follows: Gowa Regency with 6 informants, Pangkep Regency with 8 informants, North Toraja Regency with 7 informants, and North Luwu Regency with 10 informants. These key informants were selected based on various criteria as explained in the research method section.

Voters who were unregistered in the DPT or did not receive the C6 Form obtained information regarding the policy of using KTP and other identifications for the 2015 local election in South Sulawesi from various sources of information as follows. Some voters gained information from mass media such as television. Information regarding this policy was also acquired by voters from Poll Workers (KPPS), neighbors, heads of hamlet/sub-village and heads of village/ward. Some voters also got their information from places of worship and traditional markets which were frequented by Regional/Municipal KPU who disseminated information there.

Regarding the characteristics of voters who used KTP or other identifications, this study identified three main reasons for using KTP in the 2015 local election. Firstly, the group of voters who did not receive invitation to vote or C6 Form from the Poll Workers (KPPS). This is due to a number of factors which can be explained by cases found in the field. The first case, voters using KTP did not receive C6 Form because they were not registered in the DPT. It is interesting to note that these voters were in fact registered in the DPT for the 2014 legislative election and the 2014 Presidential election, yet they were unlisted in the DPT for the 2015 local election. This was the case experienced by informants in: Lembang Tallu Lolo Village, Kesu District, North Toraja Regency; Malino Ward, Tinggi Moncong District, Gowa Regency; Pandang-Pandang Ward, Somba Opu District, Gowa Regency; Samalewa Ward, Bungoro District, Pangkep Regency.

Secondly is case of the group of voters who were listed in the DPT but did not receive C6 Form from the KPPS. This condition was experienced by a number of informants in the following location: Kasimbong Ward, Masamba District, North Luwu Regency. The second characteristic applies to voters who had just relocated to another residence so their names were not included in the Permanent Voters List (DPT). These voters who relocated did not request a relocation notification letter from the Village/Ward Voting Committee wherein they could have simply shown their 
KTP to the KPPS to be listed in the Additional Voters List 2 (DPTb-2). This case occurred in several locations, among others were: Tampo Tallunglipu Ward, Tallunglipu District, North Toraja Regency; Mandalle Village, Mandalle District, Pangkep Regency.

Thirdly is characteristic applies to voters who were not present during voter registration hence their names were unregistered in the DPT. This occurred due to two main reasons. Firstly, the voter works or resides in another region, which may be due to continuing their studies in another city, rendering them unregistered during the period of voter data update although they did return to their localities when the local election was held. This case happened among others in: Rantepao Ward, Rantepao District, North Toraja Regency. Secondly, the voter married someone residing in another district and had relocated to live with their spouse. During voter data update, the person was not registered as a voter as she/ he was regarded to have relocated to live with their spouse. Yet, at the time the local election was conducted, they returned to their initial residence and exercised their voting rights using KTP. This case occurred in a number of locations, among others: Tondongkura Village, Tondong Tallasa District, Pangkep Regency; Mattirokanja Village, Liukang Tuppabiring District, Pangkep Regency.

In addition to the issues above, voters using KTP and other identifications had two differing responses to this policy. The first response is that several voters appreciated the policy on the use of KTP and other identifications so they did not loose their right to vote just because they were not registered in the DPT or did not receive the $\mathrm{C} 6$ form. Some voters in this group have experienced losing their voting rights because they were unlisted in the DPT of the previous general election wherein the policy concerning the use of KTP and other identifications were yet to be implemented. As stated by one of the informants from the Mattirokanja Village, Pangkep Regency:
"Praise be to Allah; I could finally vote using my KTP because if I couldn't then I would have again lost my right to vote."

A similar response was delivered by an informant from the Village of Lembang Nonongan, North Toraja Regency:

"I am saved with the advent of this regulation on using KTP for those who haven't registered to vote, because my voting rights in the local election is not lost."

The second response is that a number of voters using KTP and other identifications did not appreciate the policy, particularly concerning the time limitation which is different to voters registered in the DPT. They thought that this policy positioned the group of voters using KTP and other identifications as illegal or unofficial voters as their election schedule was different than the others. Additionally, the time limitation tends to lead voters not to come and vote even after they have registered as voters using KTP or other identifications because they already have other agenda after 12 p.m. This was stated by an informant from the Mandalle Village, Pangkep Regency:
"Becoming a voter using KTP means you can't come and vote at your own leisure because you can only vote after 12 noon. So, sometimes I'm lazy because I feel uncomfortable we are considered as an unofficial or illegal voter."

This study also indicates that there was no gender influence in the use of KTP in the 2015 local election. However, this research observed the possibility of age and location being influential in the use of KTP. The influence of age and education factors in using KTP may happen to voters who were students (high school or university) pursuing education 
in another region and returned to their home residence during the local election. In a number of cases, an indication of voter mobilization was found wherein a certain candidate funded transportation cost for all university students to return to their hometown at the time of the local election. Additionally, the factor of residential location (urban or rural) also tended to influence the use of KTP wherein it is indicated that several of the regions with voters using KTP were rural areas. This, among others, may be due to several voters being farmers who were usually not present at home during the re-registration. Moreover, they generally did not know where to go to check the DPT and ensure whether their name has been listed or not.

\section{Administrators of The 2015 Local Elections and Voter Data Update Officers}

In analyzing the impact of KPU Regulation No. 4 Year 2015 which, among others, regulate the use of KTP and other identifications in general/local elections, this article focuses on three local election administrators namely the Regional/Municipal General Elections Commission (KPU), the Regional/Municipal Election Supervisory Committee (Panwaslu) and the Voter Data Update Officers (PPDP). The first two institutions are major players in the conduction of local elections, particularly in terms of implementing PKPU No. 10 Year 2015. This study also explored the role of PPDP to obtain in-depth information regarding the main reason for voters remaining without proper registration in the Temporary Voter List (DPS) thus causing them to use KTP or other identifications. These three institutions were sequentially analyzed as presented in the following passages.

\section{- Regional/Municipal KPU}

Regarding the perspective on the role of Regional/Municipal KPU in the use of KTP and other identifications, this study focuses on the regulations or programs that corresponds to this policy. The KPU Regulation No. 9 Year 2015 which regulates the use of KTP and other identifications does not stipulate in detail whether voters should show their KTP/other identifications or should it also be attached with a photocopy. This study found there were numerous interpretations concerning this policy, particularly to KPPS (Poll Workers) in the various regions, as shown in Table 2 below.

As an example, the KPPS in TPS (Polling Station) 4, Passele Ward, Rantepao District, requested voters who were unlisted in the DPT and did not receive the $\mathrm{C} 6$ form to merely show their original KTP before casting their vote. However, the KPPS in TPS 8, Malango Ward, Rantepao District had a different policy which required voters to bring their original KTP and submit its photocopy which proves that the voter's residence is within the surrounding premises of the TPS. The policy implementation in North Toraja Regency was almost similar to Pangkep and Gowa Regencies wherein voters using KTP or other identifications had to show their original KTP or Family Registry and submit KTP photocopy to the KPPS. As for KPPS in the North Luwu Regency, they requested voters who were unregistered in the DPT and did not receive C6 Form to bring and show their original KTP or Family Registry without having to submit KTP photocopy to the officers.

Besides KTP and Family Registry, other identification documents which can be used, according to the KPU Circular Letter No. 1003/KPU/XII/2015 point 7, is a residential notification letter issued by the Head of Village/ Ward. Regarding the interpretation of other identification document types, particularly the residential notification, in some cases it was not recognized as other identification documents. As an example, the KPPS in TPS 8, Lingkungan Tosala, Malango Ward, Rantepao District, North Toraja Regency did not acknowledge residential notification letters 


\section{Table 2.}

Implementation of PKPU No.10 Year 2015 by 4 Regional/Municipal KPUs of South Sulawesi in the 2015 Local Election

\begin{tabular}{|c|c|c|}
\hline $\begin{array}{c}\text { Regency/ } \\
\text { Municipality }\end{array}$ & Policy Implementation & Supporting Policy \\
\hline Gowa & $\begin{array}{l}\text { Show original KTP/Family Registry and } \\
\text { submit photocopy of KTP to KPPS }\end{array}$ & $\begin{array}{l}\text { - No special regulation } \\
\text { - Composed a guidebook based on PKPU No.10 } \\
2015\end{array}$ \\
\hline Pangkep & $\begin{array}{l}\text { Show original KTP/Family Registry and } \\
\text { submit photocopy of KTP to KPPS }\end{array}$ & $\begin{array}{l}\text { - No special regulation } \\
\text { - Strengthen information dissemination and } \\
\text { elaborations to officers at PPS and to KPPS }\end{array}$ \\
\hline North Luwu & $\begin{array}{l}\text { Show original KTP/Family Registry (without } \\
\text { having to submit KTP photocopy to KPPS) }\end{array}$ & $\begin{array}{l}\text { - No special regulation } \\
\text { - Assembled all PPK and disseminated information } \\
\text { on PKPU No.10 } 2015\end{array}$ \\
\hline North Toraja & $\begin{array}{l}\text { - Show original KTP/Family Registry } \\
\text { - Show original KTP/Family Registry and } \\
\text { submit photocopy of KTP to KPPS }\end{array}$ & $\begin{array}{l}\text { - No special regulation } \\
\text { - Merely issued a circular letter based on PKPU } \\
\text { No.10 } 2015 \text { to PPS and KPPS }\end{array}$ \\
\hline
\end{tabular}

Source: processed data from interviews conducted in August 2016

as other identifications as they only recognized original KTP.

Generally, the Regional/Municipal KPU did not draft any special regulation in relation to PKPU No. 102015 on Updating of Voters List and Data in the Election of the Governor and Vice Governor, Regent and Vice Regent, Mayor and Vice Mayor, and PKPU No. 10 year 2015 on Polling and Counting of Votes for the Election of the Governor and Vice Governor, Regent and Vice Regent, Mayor and Vice Mayor. The North Toraja Regional KPU made a circular letter concerning the use of KTP and other identifications to KPPS by attaching PKPU No. 10 Year 2015. The Gowa KPU reprinted the guidebook from Central KPU and distributed them to PPK and PPS to be distributed to all KPPS in the Gowa Regency two weeks prior to the election date. This guidebook also provided explanations regarding the use of KTP and other identifications for voters who are not registered in the DPT or did not receive the C6 Form. The North Luwu and Pangkep Regional KPUs did not distribute any special circular letter concerning this policy and they did not issue the PKPU No. 10 Year 2015 document to their staff in the PPS and KPPS. The North Luwu and Pangkep KPUs only re-emphasized the explanation regarding this policy directly to the KPPS during the Technical Assistance preparation event for the 2015 local election.

\section{- Elections Supervisory Committee (Panwaslu)}

After discussing the Regional/Municipal KPU, we will observe the Regional/Municipal Elections Supervisory Committee (Panwaslu) who were tasked to monitor the conduction of the 2015 local election. The Regional/Municipal Panwaslu comprised of three members, with each of the three members being present at the district and village levels as well as monitoring every TPS during the election day. This research is focused on the efforts of the Regional/Municipal Panwaslu in anticipating the possibility of fraud as an impact from the issuance of PKPU No. 10 Year 2015.

With limited authority and resources, the Regional/Municipal Panwaslu did not have any special policy regarding PKPU No. 10 Year 2015. Nevertheless, the Regional/Municipal Panwaslu employed several strategies by increasing collaborations with key stakeholders in monitoring the local election, as shown in Table 3.

Table 3 shows that all Panwaslu at the four research locations responded to PKPU No.10 2015 in similar manner which is by disseminating information to supervisory 
Table 3.

Response of 4 Regional/Municipal Panwaslu of South Sulawesi on the Policy of Using KTP and Other Identifications in the 2015 Local Election

\begin{tabular}{|c|c|}
\hline $\begin{array}{c}\text { Regency/ } \\
\text { Municipality }\end{array}$ & Supporting Policy \\
\hline Gowa & $\begin{array}{l}\text { - No special regulation made relating to the policy on using KTP and other identifications. } \\
\text { - More wide-spread dissemination of election supervision and monitoring, particularly regarding } \\
\text { the process of using KTP and other identifications during local election day. }\end{array}$ \\
\hline Pangkep & $\begin{array}{l}\text { - Received circular letter from the Indonesian Elections Supervisory Agency (Bawaslu) and did not } \\
\text { draft special regulation at the local level and did not follow up on the special circular letter received. } \\
\text { - Disseminated information to the District Elections Supervisory Committee and the On-Field } \\
\text { Elections Supervisory Officers (PPL) to monitor voters particularly during the election day. }\end{array}$ \\
\hline North Luwu & $\begin{array}{l}\text { - Received and studied PKPU No. } 92014 \text { and the Circular Letter from Bawaslu regarding the use } \\
\text { of KTP and other identifications. } \\
\text { - Disseminated information regarding PKPU to voting officers at the district and all supervisory } \\
\text { officers and request for them to specifically monitor the use of KTP and other identifications on } \\
\text { the day of the election. }\end{array}$ \\
\hline North Toraja & $\begin{array}{l}\text { - Received Circular Letter from the Bawaslu regarding monitoring the use of KTP, Residential } \\
\text { Notification Letter, and C6 Model but did not draft any special regulation in response. } \\
\text { - Called upon Supervisory Officers at the TPS to actively monitor and match KTP and other } \\
\text { identifications on the day of the election. }\end{array}$ \\
\hline
\end{tabular}

Source: processed data from interviews conducted in August 2016

institutions at the district level to enhance monitoring in the use of KTP and other identifications. Moreover, Panwaslu also established collaborations with various parties to undertake monitoring activities. As an example, the Pangkep Regional Panwaslu established collaboration with the police, district attorney, media, social organizations, nongovernment organizations, and religious figures. Additionally, Pankep Regional Panwaslu also involved students through a public debate activity on election supervision and the winner of the debate became the Local Elections Supervisory Ambassador.

The North Toraja Regional Panwaslu also established collaborations with key stakeholders in monitoring the 2015 local election. They collaborated with religious organizations, local NGOs, local media, and youth organizations such as the North Toraja Regional Indonesian National Youth Council (KNPI). The North Toraja Regional Panwaslu also recruited monitoring officers at the TPS level who had began working 23 days prior to the election day.
The Gowa Regional Panwaslu also collaborated with the police, district attorney, social organizations, local NGOs, local media, and student organizations as well as community figures during the 2015 local election. For TPS level monitoring, the Gowa Regional Panwaslu recruited 1000 monitoring officers (in accordance to the number of TPS in the Gowa Regency) to ensure the voting process runs well.

As for the North Luwu Regional Panwaslu, they also collaborated with key stakeholders in conducting supervision and monitoring. Moreover, the North Luwu Regional Panwaslu also maximized the use of social media in receiving complaints of occurring violations, such as via Facebook. Aside from social media, the complaint process could also be done through text messages (SMS) to ease the provision of complaint services, keeping in mind that the North Luwu region is located in a mountainous area that is not accessible by public transport and is inaccessible via mobile telephone network. Specifically, in this region, the North Luwu Panwaslu routinely conducted 
direct visitations to undertake monitoring activities and receive any complaints available.

Concerning violations found in the use of KTP and other identifications, Panwaslu in the four research locations did not find any violation directly connected to the misuse of KTP or other identifications. Nevertheless, a number of Panwaslu findings in certain cases were indirectly connected to PKPU No. 10 2015, such as the finding of the North Toraja Regional Panwaslu on the use of C6 Form by another person which did not match the data written on the invitation in the Tallulipu District. Another finding concerned a 13 years old child who brought a C6 Form intending to vote. These cases were, however, resolved by the TPS monitoring officer and the District Panwaslu by not providing ballot paper to the two individuals bearing the C6 Form.

Another case found by the North Luwu Panwaslu was a voter who wanted to use a residential notification letter to cast a vote. The KPPS then rejected the voter with a suggestion from the monitoring officer because they required the use of KTP or Family Registry instead of mere residential notification letter. The North Luwu Regional Panwaslu also explained that the amount of KTP users in North Luwu during the 2015 local election increased compared to the Presidential Election because students who were generally living outside of North Luwu returned to their home and voted using their KTP so as not to loose their voting rights.

As for the 2015 Pangkep local election, the Pangkep Regional Panwaslu found cases of undistributed C6 Forms, double registry in the DPT, and voters representing others on election day with the excuse that the original voter is ill. In the Gowa Regency, the Panwaslu of Gowa Regency found several cases of KTP use by voters residing in another district, for instance in Bajeng District.

- Voter Data Update Officer (PPDP)

The final component in the administrators of the 2015 local election relating to the use of
KTP and other identifications was the Voter Data Update Officer (PPDP). This research focuses on two main issues, i.e. first: influential factors on the high rate of voters using KTP and other identifications; second: structural and on-field obstacles encountered by PPDP during the process of updating the 2015 local election voter data.

Based on the interview results of PPDP in North Luwu, the background in the high rate of voters using KTP and other identifications in the region was caused by a number of cases. The first case refers to several Indonesian Migrant Labor (TKI) working abroad (Malaysia) who were not registered during the voter data update but just prior to election day these voters returned home and used their KTP to cast their ballot during the local election. The second case refers to students living in other cities who were not registered by the PPDP but returned home prior to election day and subsequently used their KTP to exercise their voting rights during the election. Based on these findings, it is indicated that there was a possibility of students and TKI being mobilized by the campaign team of a candidate to return home to North Luwu before election day and to use their KTP or other identifications for casting their vote.

As for the case in Pangkep Regency, this study identifies coomon reason behind the high rate of voters using KTP or other identifications was due to the large number of residents working outside the region who would then return home during the election. Another reason for it is that some residents had relocated to another region after the data update causing that individual to be unregistered in the DPT and they had to use KTP on election day.

The high rate of voters using KTP and other identifications in North Toraja, according to the PPDP, was due to the campaign team of candidates inviting voters who were outside of the region to return and cast their vote, 
although they were not registered in the DPT, by using their KTP and other identifications. Additionally, many voters did not yet have KTP at the time so they requested for residential notification letter from the head of village/ward in order to be used for casting their votes.

In the Gowa Regency 2015 local election, one of the reasons in the high rate of voters using KTP and other identifications, according to PPDP, is that they found it difficult to meet residents from morning till afternoon, thereby making it difficult to register them in the voter data update process. The following was stated by a PPDP officer from the North Toraja Regency:

"...we had difficulty in meeting residents in this region because they generally work as traders in the Rantepao central market (urban area) ..."

Similar conditions were mentioned by PPDP officer from North Luwu Regency:

“...It was difficult for us to reregister residents' data here. There were some residents who were not present when we visited them during the day, they may have gone to the field or the market. And when we visited them at night, they were already asleep. So these types of resident were usually difficult for us to record properly ..."

The second issue explored in the PPDP concerns obstacles faced by officers in the process of data update. Generally, officers consider their main obstacle to be the time limitation for data update which was only two months. Some officers suggested data update process be conducted every month with the collaboration of the Civil Registry Office. Another obstacle faced by officers in the process of data update is difficulty in meeting with residents who usually work at the market or in the field throughout the day, this case is of particular note in the North Toraja, Pangkep, and North Luwu Regency.

Additionally, PPDPs consider that the data that had been updated and submitted to the Regional/Municipal KPU and then returned to the PPS in the form of DPS did not undergo any changes at all and it was the same as data from the previous data update officer. This made PPDPs consider that the data updating process did not have positive impact on the DPS data since the updated data was not used in the first place. The following was stated by a PPDP officer from the Gowa Regency:

"Usually the DP4 data that we've
updated on the field were not
followed up. For example; there's
data of a resident who passed away
and we've crossed off their name
when doing the update and the
data had been reported to the KPU.
But when the DPT was announced,
the data of the individual who was
crossed out still showed up."

Another obstacle faced by PPDP is the lack of positive response from the community toward the officers during the updating process, some even refused to be interviewed by the officers. This, among others, was experienced by one of the PPDP officers in Gowa Regency who stated:

“...another obstacle that we usually experienced in the field was that there were still residents who did not want to help or understand. For example, there was a person who did not want to open their door when we wanted to update their family data ..."

This condition shows the lack of community participation in voter data update. This is possibly due to the lack of information dissemination conducted by the Regional/ 
Municipal KPU assisted by the Head of Village/ Ward to their residents in supporting the voter data updating process.

In sum, voter registration is still common problem in most general and local election that may influence the quality of election process due to inaccessibility issue and voting right violation. By this line, the Indonesian government should concern on population administration that regularly updated and can be utilized by the Election Committee in registering voters. In addition, citizens engagement in election monitoring is critical in order to ensure election is conducted accountably and accessibly.

\section{Conclusion}

This study explored the dynamics of voters using KTP or other identifications in the 2015 South Sulawesi Local Election based on two main point of discussions. Firstly, analyzing the reasons voters used KTP or other identifications in the 2015 local election. Secondly, describing the responses of General/ Local Elections administrators concerning KPU's policy on voters using KTP and other identifications in the 2015 local election. This article was able to identify three main characteristics of voters using KTP or other identifications. The first characteristic refers to voters who did not receive C6 Form from the Poll Workers (KPPS). The second characteristic applies to voters who were newcomers in a region and was previously unregistered and did not ask for a relocation notification letter. The third characteristic can be observed in voters who were unregistered during the voter data updating process. Regarding unregistered voters, there are two main causes for voters to be unregistered, i.e.: firstly, the voter was working in another region; and secondly, the voter had gotten married and was residing in another region but returned to their home town to exercise their voting rights.
The responses of local election administrators to the KPU policy No. 9 Year 2014 were varied. The Regional/Municipal KPU, for instance, had applied differing policies in interpreting the Central KPU policy. As for the Panwaslu, they conducted monitoring efforts to ensure proper policy implementation so that it does not trigger actions in violation of election regulations such as mobilizing the masses to using KTP or other identifications. Although in reality, the Panwaslu in the four research locations did not find any indication of violation taking place. Subsequently, there is the response of Voter Data Update Officer (PPDP) who was a key player in maintaining voter data quality. Based on this group of informants, there are two causes identified in the high rate of voters using KTP or other identifications in the 2015 local election in South Sulawesi. Firstly, there was a wave of arrival of Indonesian migrant workers who were living in Malaysia at the time of the local election. Secondly, it is indicated that there was a mobilization of students living outside the region to return home during the local election. In general, this study supported the thesis of Rolfe (2012) and Geys (2006) which emphasized the factor of election institutions as one of the major factors affecting voter participation in general elections, this condition tends to apply to countries with transitional democracy in which the election administration system has not been properly set up yet. This is caused, among others, by poor civil registry data management in Indonesia which has not been resolved as of current and is a consequential impact from the failure in civil registry using the e-KTP system. The horrendous cases concerning the DPTs which often became the problem in every conduction of general or local elections would have been avoidable if only all Indonesian civil registry data had been integrated properly and managed professionally. 


\section{Annotation}

This article was composed bassed on a research report titled "Riset Tingkat Partisipasi Masyarakat dalam Pemilu; Studi Kasus Pemilih Pengguna KTP dan Identitas Lain di Prov.Sulawesi Selatan" (Research on Community Participation Level in the General Election; Case Study of Voters Using KTP and Other Identifications in the South Sulawesi Province) which was completed in August 2016. This research was conducted by all the writers of this article and it was funded by the Indonesian General Elections Commission (KPU).

\section{References}

Aminuddin, M. F. (2016). Electoral System and Party Dimension Assessment in Democratic Indonesia. Jurnal Ilmu Sosial dan Ilmu Politik, 20(1), 1-15. doi: 10.22146/ jsp.17956

Blais, A., Massicotte, L., \& A. Dobrzynska. (2003). Why is Turnout Higher in Some Countries than in Others?, Retrieved August 9, 2016, from http://www.elections.ca/res/ rec/part/tuh/TurnoutHigher.pdf

Bourne, P. A. (2010). Modelling Political Trust in a Developing Country. Research Journal of Social Sciences, 2(2), 84-98.

Endersby, J. W., \& Krieckhaus, J. T. (2008). Turnout Around The Globe: The Influence of Electoral Institutions on National Voter Participation, 1972-2000. Electoral Studies, 27, 601-610.

Geys, B. (2006). Explaining Voter Turnout: a Review of Agregate-level Research. Electoral Studies, 25, 637-663.

Grönlund, K., \& Setälä M. (2007). Political Trust, Satisfaction and Voter Turnout. Comparative European Politics, 5(4), 400-422.

Grimmelikhuijsen, Stephan. (2012). Transparency and Trust; an Experimental Study of Online Disclosure and Trust in Government. A PhD Dissertation in Utrecht School of Governance. Netherlands: Universiteit Utrecht.
Hooghe, M., \& Marien, S. (2013). A Comparative Analysis of The Relation Between Political Trust And Forms of Political Participation in Europe. Journal European Societies, 15(1), 131-152.

Institute for Democracy and Electoral Assistance. (2016). Voter Turnout Database. Retrieved February 18, 2017, from http://www.idea.int/themes/voterturnout.

Lipset, S. M. (1981). Political Man: The Social Bases of Politics. Baltimore: The Johns Hopkins University Press.

Merrifield, J. (1993). The Institutional and Political Factors that Influence Voter Turnout. Public Choice, 77, 657-667.

Oliver, J. E. (2000). City Size and Civic Involvement in Metropolitan America. American Political Science Review, 94, 361-373.

Powell, G. B. (1982). Contemporary Democracies: Participation, Stability, and Violence. Cambridge: Harvard University Press.

Rolfe, M. (2012). Voter Turnout: A Social Theory of Political Participation. New York: Cambridge University Press

Solt, F. (2010). Does Economic Inequality Depress Electoral Participation? Testing the Schattschneider Hypothesis. Political Behavior, 32, 285-301.

Stockemer, D., LaMontagne, B., \& Scruggs L. (2013). Bribes and Ballots: The Impact of Corruption on Voter Turnout in Democracies. International Political Science Review, 34(1).

Verba, S., \& Norman H. N. (1972). Participation in America: Political Democracy and Social Equality. New York: Harper and Row.

Wong, T. K., Wan P., \& Hsiao, H. M. (2011). The Bases of Political Trust in Six Sosian Societies: Institutional and Cultural Explanations Compared. International Political Science Review, 32(3), 263-281.

Wagner, A.F., Schneider, F., \& Halla, M. (2009). The quality of institutions and 
satisfaction with democracy in Western Europe - A panel analysis. European Journal of Political Economy, 25(1), 30-41.
Yani, Andi A. (2015). The Dynamic of Indonesian Political Trust in the Beginning of Reform Era. Jurnal Penelitian Politik, 12(1), 55-68. 